\title{
Study on the Effectiveness of Question-answer Small-class Teaching Mode in the Science and Engineering Education
}

\author{
Lili Li \\ Harbin University of Science and Technology \\ College of RongCheng \\ RongCheng, China \\ hlgrongchenglll@163.com
}

\author{
Yulong Wang \\ Harbin University of Science and Technology \\ College of RongCheng \\ RongCheng, China \\ fly712@126.com
}

\begin{abstract}
It is the strongest motivation and the theme to fight a first-class education in teaching work. The teaching work includes studying methods of classroom teaching, promoting innovations in teaching work, and improving the teaching quality in teaching works. In this paper, the effect of question-answer small-class teaching model was analyzed in the science and engineering education, and it is found that the question-answer small-class teaching model can train men for profession to adapt to the development of the new era, and analyze problems existing in the teaching of science and engineering. The small-class teaching model is adopted. In the class of 30 people, explaining and previewing main knowledge points, asking questions, and summarizing learning contents can achieve, so that bad habits of learning can be broken when autonomic learning can achieve. It should be recommended by 30 people of small-class teaching model to improve the quality of teaching in the classroom, and to train innovative talents.
\end{abstract}

Keywords-analysis on effectiveness of models, small-class teaching, question-answer teaching model, the science and engineering education

\section{INTRODUCTION}

In china, the total number of university is 1148 in 2013, and the number of the college of science and engineering is about $96 \%$ of the total number of schools. The total number of majors in Colleges and universities is 47072 , and the number of science and engineering is 19582 , accounting for $41.6 \%$ of all. The number of students in colleges and universities is about 16743 thousand, and the number of the science and engineering students is accounting for $40.8 \%$ of the total number of students in colleges and universities, including undergraduate students about $36.0 \%$, master student about $3.8 \%$, and doctoral students about $1.0 \%$. it is known that science and engineering is a very important subject in Colleges and universities based on the above data, and the science and engineering education should be paid great attention to. [1-3].

In the modern times, the number of qualified scientists and technicians is very largely to meet the needs of countries because it is the most important period of socialist construction in our country. At present, the class teaching model in the science and engineering education is the solid foundation to train qualified engineering graduates, and the excellent teaching class mode under current national conditions is the core pillar of training excellent engineering talents.

In our country, the effect of class-teaching in college is evaluated by examination performance to test students' degree of knowledge after teachers explain and analyze knowledge points and students to preview and review knowledge points. The teaching model has been several thousand years in ideological class and engineering and technology class. The teaching method in the classroom plays an important role in the cultivation of students' creative ability. This approach is essential for developing students' basic knowledge, basic theory, basic skills and basic literacy, so to enhance the quality of classroom teaching is an important way to improve the quality of teaching. The classroom teaching in the science and engineering education is especially importance, because it is the beginning of promoting the social development and the progress of times, and it is the first step to train future talents. The knowledge structure is a ring of a ring in the science and engineering education, and you cannot learn the contents of the next link if there is no certain knowledge base. Therefore, it is more important to analyze the classroom teaching efficiency in the science and engineering, and it is necessary to improve the efficiency and quality of teaching. A high quality classroom teaching method can cultivate students with superior ability. An efficient classroom teaching mode will bring new development opportunities for science and engineering education, and add motive power to the progress of science and technology.

The main teaching model is the big-class teaching model in the science and engineering education. The model can save a lot of teaching resources, and most students can be educated under the big-class teaching model. However, the teaching mode is disadvantageous to students' individual training, the teaching reform is imperative, and the question-answer smallclass teaching model is proposed at the historic moment.[4-6]. The key and core of small class teaching lies in the change of thought. The small-class teaching model can reflects the education concept of the people-oriented, and is the pursuit of 
the unity of common education and individual education, which has important practical significance for promoting the quality education. The teaching model reform should be paid attention to the allocation of resources, scientificalness of project management, decrease the waste of funds and resources, so that the effectiveness of the small-class teaching model is improved.

\section{The New Development of ClassRoom Teaching MODEL}

Classroom teaching is the basic form of college education, which is the primary window to teach students knowledge and skills directly. Improving classroom teaching quality is not only the first step but also the only way to train exceptional talents. Excellent classroom teaching quality and teaching mode can improve students' concentration and efficiency, and finally make the students gain a good harvest. It lays a solid foundation for the cultivation of excellent innovative talents. At present, the classroom teaching at home and abroad is in the following:

\section{A. The Open Model}

Open teaching is the principal feature of questions. It can attract students' attention, arouse interest, induce learning motivation, and guide students to become involved in the learning state. In open teaching mode, the teacher is the guider and students can take an initiative to study knowledge, choice freely of teachers and learning content, which is conducive to creating initiative and creativity for students. However, open mode also has some fatal flaws. For example, the teacher's leading role and the communication between teachers and students are more likely to be ignored when students' autonomous learning is too stressed [7].

\section{B. The Case Teaching Model}

The case teaching model is based on cases. Teachers play the role of designers and incentives in case teaching model, and encourage students to take an active role in the discussion. In this mode, the teacher can lead students to think and discuss to mobilize students' learning initiative, and achieve the objective of educating benefits teachers as well as students. The student's brain is at an excited state and the best condition can be kept due to the continuous transformation of cases. The biggest characteristic of the case teaching model is authenticity. Because the teaching content is the concrete case and the vivid form is used, the content is studied and understood easily [8].

\section{The Practice Teaching Model}

Main forms of the practice teaching model include two kinds of forms: the classroom experiment and the independent project research [9]. The practice teaching model extends classroom teaching and emphasizes the combination of classroom teaching and practice. According to the teaching content and requirements, it is that teachers are as the leader, that students are as the main body, that course is as the basis, and that basic knowledge of teaching and learning is as the carrier to improve the overall quality of the student as the goal in practice teaching model.

\section{The Network Teaching Model}

Network teaching model is that the network is as the teaching tool, the teaching resource, and the teaching environment [10]. It mainly attaches importance to the interaction of network, and has the specific working regulations.

To sum up, the effect of class-teaching in college is evaluated by examination performance to test students' degree of knowledge after teachers explain and analyze knowledge points and students to preview and review knowledge points in our country. Although the classroom teaching mode has been for thousands of years in China, but it is a traditional classroom teaching basically, and the societal requirement for qualified scientists and technicians has not been met.

\section{NEW REQUIREMENTS FOR CLASS IN THE SCIENCE AND ENGINEERING EDUCATION}

At present, class teaching is the solid foundation for training of qualified engineering graduates in science and engineering undergraduate education. The teaching mode is the core pillar to cultivate excellent engineering talents which is the excellent classroom teaching model in line with the current situation.

The classroom teaching is the key link to cultivate students' basic knowledge, basic theory, basic skills and basic quality, and it plays an important part in the cultivation of students' creative ability. Therefore, to improve the quality of classroom teaching is a significant way to improve the quality of teaching. The classroom teaching of science and engineering education is especially important, because it is the first step to train future innovative talents in science and technology, and it is the beginning of promoting social progress and the progress of the times. The knowledge structure is a ring of a ring in the science and engineering education, and you cannot learn the contents of the next link if there is no reliable knowledge base. Compared with liberal arts, the classroom teaching and the difficulty of science and engineering education are even more difficult. During the course of learning in the science and engineering education, the subsequent learning process will be very difficult if an elementary course is not solid, so it is urgent and cannot relax. Therefore, classroom teaching is more significant in the learning process and students' knowledge chain is needed in order to be able to extend continuously. Efficient classroom teaching model in the science and engineering education can train undergraduate and bring additional development opportunities for the development of science and technology progress.

The model of teaching in the university is the teaching mode. This kind of teaching mode is mainly been prepared on the basis of the teacher's teaching, and is to take the lecture notes and review the class as supplementary; finally, the students' learning degree will be evaluated by attendance in class and test results. The teaching mode needs a certain requirement for both teachers and students: Teachers, who 
have the capability of profound professional knowledge and clear mind, and the ability of simplicity; at the same time, students, who have a certain learning foundation, and be able to follow the teacher's thinking and concentrate on classroom. With the influence of many factors, a lot of problems are shown gradually in recent years:

\section{A. The Tight Schedule, the Arduous Task, and the Difficult Content in Course of the Science and Engineering Education}

The class content of science and engineering has characteristics of great information and complicated content, such as concept explanation, principle analysis, formula derivation, practical application and so on. A professional course has to be done in 48 56 hours, and the full content of books is explained completely. So that students digest it difficult fully, too much of the content is interpreted, and skilled knowledge is more difficult. If the professional knowledge and skills are mastered by students, the time in the classroom is so short that most teachers describe knowledge only and that the student doesn't understand knowledge adequately. This way of teaching is cramming teaching method. The reason is that teachers explain the content too much because the time of students preparing is too little. The students' thinking time reduces because teachers need to explain important and difficult knowledge points, and describe concepts and principles.

\section{B. Making Progress Slowly of Teaching Level}

In the current teaching model, the classroom teaching content is difficult to update, and the level of teaching is also difficult to continue to progress, so that it is difficult to become a good teacher. When the teacher teaches courses a few times, the content and mode of teaching are gradually fixed, and the level of teaching is gradually slowing down, therefore, contents in the classroom cannot be updated with the development of social science and technology. The knowledge update rate of the classroom is reduced, so that the students cannot understand the new knowledge and new changes brought by development of the social science and technology. This kind of teaching model is not a good model, which is more backward in social knowledge.

The teacher needs to explain too much content in teaching. The content is from basic concepts to the analysis of principles and from the critical knowledge point and difficult knowledge point to realistic application, which cannot be abandoned, so the knowledge structure of teachers is fixed. Firsthand knowledge and content are without a place to lay due to the fixed knowledge structure and too much teaching content. Therefore, teachers' teaching level is gradually fixed, and it is difficult to go up for further improvement.

\section{Weakening Learning Enthusiasm of Students}

With the rapid development of communication technology, the use of smart mobile phone and computer is extensive, and various entertainments also changed rapidly. In this environment, mobile phones are held by more and more students, so that the knowledge is very difficult for students of science and engineering. At the same time, the students' learning time is greatly reduced, so that it is difficult to become a practiced science and engineering talent. At present, students' self-control is weak to face a variety of entertainment equipment and the main objective is passing through tests, so the requirement for self is moderately relaxed.

To sum up, specialized ability of students is more and weaker and knowledge mastered is worse under the current classroom teaching model in the science and engineering education. The question can be solved effectively by questionanswer small-class teaching model.

\section{ANALYSIS ON EFFECTIVENESS OF QUESTION-ANSWER SMALL-CLASS TEACHING MODEL}

The small-class teaching model is the mode of the number of less than 30 people. The question-answer model is the model that teachers give content easily and that students prepare for knowledge points. In the classroom, the student is mainly asking questions, and teachers explain the indispensable points as auxiliary. The question-answer smallclass teaching model can improve the quality of teaching, and cultivate outstanding talents of science and engineering.

\section{A. The Effectiveness of Question-answer Small-class Teaching Model}

1) The cultivation of students' consciousness: In order to improve the efficiency of classroom and independent thinking ability of students, teachers and students should do some preparation work for classroom teaching. First of all, teachers need to give an assignment of the lecture and set standards for evaluating of preparation lessons before class, including basic concepts, basic principles, indispensable points of knowledge, and so on. Secondly, students need to prepare for learning content and understand the key and difficult points, so that questions can be raised and examined in class. In the classroom, the teacher can ask students to respond to the questions and do not explain basic and easy knowledge. Therefore, teachers can reduce the content and improve the quality of classroom teaching. Finally, self-study ability and self thinking ability of students can be guided.

2) The improvement of students' enthusiasm: The smallclass teaching is the basis of the realization of science and engineering talents training in a virtuous circle, and it is the basis for the preparation of students before class. However, students' self-control ability is poor and students are easy to be tempted by the temptation of external entertainment, the situation often appears that students do not preview. Therefore, teachers should give appropriate guidance in the initial stage of learning, and raise students of learning enthusiasm; at the same time, appropriate methods need to be adopted to impose a certain learning pressure. The small-class teaching model is the question-answer teaching model, and the final score is based upon the state of answering questions and the preparation of course. The teaching mode has the following advantages: first of all, there are 10 to 20 questions during a class in the small class of 30 and each student is very easily to be asked, so that the trusting to luck is eliminated and the 
classroom content is actively prepared. Secondly, there is the bandwagon effect, and students prepare and respond positively to question. Finally, students will gradually enhance their selfconfidence, improve learning ability constantly and increase the interest slowly. In the end, it will form a virtuous circle and improve students' enthusiasm.

3) The introduction of new knowledge: There are some omissions or shortcomings when students prepare lessons before class, and the teacher gives analysis of complicated knowledge and doubtful points. Firstly, questions must explain clearly, which are found through preview and brought into classrooms. Secondly, the knowledge point is the core of content, it can meet the desire knowledge to explain the doubtful points and be conducive to the subsequent course. When the teaching content can be done easily, teachers can expand contents, including new social skills and ideas. Therefore, the social scientific and technological progress is understood easily, students' learning initiative is enhanced, and finally innovative thinking is developed.

In a word, the question-answer small-class teaching model can effectively improve quality of teaching, and students can be cultivated to excellent graduates, excellent scientific and technological talents and innovative talents.

\section{B. Notes of the Question-answer Small-class Teaching Model}

The Science and engineering education is not only bearing the responsibility to develop talents of basic research and engineering and technical personnel, but also the basis and source of the development of engineering technology and interdisciplinary subject. The new path of industrialization with Chinese characteristics be taken and the goal can be achieved that is building innovative country, the construction of the talent powerful nation and other. The talent is need who is innovative talents in the science, technology and engineering, and a large number of application talents. The cultivation quality of science and engineering talents directly relates to the national independent innovation ability and the international competitiveness of the entire nation in the future.

It should pay attention to the following points in the question-answer small-class teaching model. First of all, students should be encouraged to learn by themselves and guided in the right way. Second, questions should be moderate and can be discussed with students in the classroom. Third, students can also introduce a question and express different views, and students' ability is cultivated to think independently. Fourth, the depth of questions and the direction of the guide is different, with the student's grade and learning the direction is different.

\section{SUMMARY}

The question-answer small-class teaching model is not a clear teaching methods and educational philosophy, and should be combined with the specific course content in different majors. So that there are different teaching methods according to the different nature of the curriculum, curriculum content and teaching objectives. The small-class teaching model indicates the direction of future development for the traditional class teaching system, and opens up a new way of thinking by changing the current class teaching. It can meet the needs of education for the future, to meet the requirements of education for technology talents, and to meet the development trend of educational progress. In summary, The small-class teaching model is an opportunity to deepen the educational reform.

The effectiveness of classroom teaching can be analyzed by the question-answer small-class teaching model and the bottleneck can be solved in the cultivation of science and engineering undergraduate students. It can be improved including self-learning ability of students, guidance of teachers and the implementation of training system, so that students have self-confidence, truth-seeking and the fun of learning gradually. The new teaching model will lay a solid foundation for the cultivation of science and engineering talents who have the ability of an independent mind and innovation.

\section{REFERENCES}

[1] SU Wen-ping, "Participation-Model Didactics for Undergraduates in China,” Journal of Beijing University of Aeronautics and Astronautics (Social Sciences Edition). vol. 22, pp. 74-77, September, 2009. (In Chinese)

[2] WU Ai-hua and LIU Xiao-yu, "Promoting the innovation of cultivating mechanism of science and engineering talents," Research in Higher Education of Engineering. pp. 1-7, 2014. (In Chinese)

[3] ZHANG Zheng-xia and ZHANG Yanhong, "On the teaching mode of small Class teaching in"Computer program design”," Education Modernization. pp. 67-69, August, 2015. (In Chinese)

[4] YANG Ni-ping, "Analysis on the rationality of small class education,” Journal of Inner Mongolia Normal University (Educational Science). vol. 23, pp. 29-31, August, 2010. (In Chinese)

[5] LIU Jing-yan, “On the small teaching in universities,” Journal of Jiangxi Science \& Technology Normal University. pp. 119-123, August, 2013. (In Chinese)

[6] YU Gang, TAN Quan, PAN Yuan-mei, HAN Yu, DONG Qi-zhi and ZHANG Jun, "Research on a Novel Teaching Mode of Physical Chemistry,” Chemical higher education. pp. 21-23, 2014. (In Chinese)

[7] HUANG Yan-yan, "On Open Education and Its Pedagogical Significance," Journal of Henan University of Technology: Social Science Edition. vol. 4, pp. 83-98, 2008. (In Chinese)

[8] YANG Xu-hua, "Simple Talk about Advantages and Functions of Common Teaching Models,” education space. pp. 190-191, 2010. (In Chinese)

[9] LI Shu-wen, "Building Practice Teaching Mode to Improve Teaching Effectiveness of Ideological and Political Course in University,” Theory and Practice of Education. vol. 31, pp. 27-29, 2011. (In Chinese)

[10] ZHAO Jin-bo, "Simple Talk about the Rational Choice of Practicing Teach Model,” Journal of Weifang University. vol. 6, pp. 129-130, 2006. (In Chinese) 